\section{Cyclones of the South Indian Ocean.}

V R. R. A. WATSON, when director of the Royal II Alfred Observatory, Mauritius, began a series of annual papers dealing with each cyclone season in that part of the South Indian Ocean lying near and to the east of Mauritius. They are published in the Miscellaneous Publications of the Royal Alfred Observatory. The second of the series, entitlod "The Cyclone Season 1928-1929", shows that the season in question was a normal one in regard to the number of cyclones (8) that were noted. None of these storms caused damage in Mauritius, but Rodrigues suffered severely in January 1929.

The paper contains, in addition to the particulars of this one season, statistical information about the seasonal distribution and the movomonts of eyclones between the equator, lat. $30^{\circ} \mathrm{S}$. and long. $50^{\circ}$ and $70^{\circ} \mathrm{E}$., based on 77 years' records beginning in 1848 that are not available elsewhere. This information extends and brings more up to date a part of the statistics that appeared in "Hurricanes and Tropical Revolving Storms", by Mrs. E. V. Newnham (Geophysical Memoir, No. 19), issued by the Meteorological Office, London, eight years ago. The manuseript records of the Observatory were used in addition to published information. Speaking of the seasonal variation in the number of cyclones recorded on each date, the author says: "The yearly variation is best represented by a slow rise throughout October and November, then a somewhat rapid rise to a maximum about Feb. 4, and a gradual fall to the end of May".

It may be noted that before the publication of the memoir referred to above, the best authority for the seasonal variation in the frequency of storms in the whole of the South Indian Ocean was Meldrum, who found from a consideration of 35 yeurs' observations, also beginning in 1848 , that more storms occurred in January than in February -71 as against 61 -which implied an earlier date for the maximum than is now indicated. Mrs. Newnham's figures for the wider area accord well, however, with those found by Watson.

Watson also gives statistics in regard to the frequency with which all cyclones that crossed latitudes $10^{\circ}, 15^{\circ}, 20^{\circ}, 25^{\circ}$, and $30^{\circ}$ S. moved in the various directions: north, north-north-east, north-east, and so on. His remarks upon these have an important bearing upon the general question of the motion of tropical cyclones. He says, "The table is strongly suggestive of wind diagrams for various heights above the surface at Mauritius, the low latitudes corresponding to small heights and the higher latitudes to heights of 4 or 5 kilometres. . . Given that the surface of separation between tho easterly trades and the westerly 'anti-trades' slopes upwards from the surface about latitude $30^{\circ} \mathrm{S}$. to reach very big hoights about latitude $10^{\circ} \mathrm{S}$., and that a cyclone is carried along by the prevailing current where condensation is taking place most vigorously, we should expect some such similarity." Before, however, this explanation can bo accepted, it appears desirable to have direct evidence that the principal rain clouds show the very large variation in height in different latitudes that is im plied. The suggestion opens up an interesting line of possible research.

\section{University and Educational Intelligence.}

CAMBrToge. - The professor of chemistry has, with the consent of the Vice-Chancellor, appointed S. E. Janson, of Gonville and Caius College, to be his assistant for five years as from July 1 last.

The Busk Studentship in aeronautics, founded in memory of E. T. Busk, who lost his life in 1914 whilst flying an experimental aeroplane, has been awarded for the year 1930-31 to R. H. Francis, of the University College of North Wales, Bangor.

N. F. Mott has been elected to an official corporate fellowship at Gonville and Caius College on his appointment as lecturer in mathematics. Mr. Mott was formerly a scholar of St. John's College, gained a first class in the Mathematical Tripos, Pt. I., and was a wrangler with distinction in Pt. II. in 1926. After working in Copenhagen, he was appointed lecturer in theoretical physics in the University of Manchester.

LONDON.-Notice is given that the Rogers prize for 1931 , value $£ 100$, is offered for an essay on "Filtrable Viruses as a cause of Disease in Man ". The competition is open to all persons whose names appear on the Medical Register of the United Kingdom. Copies of the regulations, including information regarding the date in April by which essays must be received, may be obtained on application to the Academic Registrar, University of London, South Kensington, S.W.7.

A scrorarshrp has been founded at University Colloge, Southampton, by friends of the late Dr. Alex Hill, in recognition of the distinguished services rendored by him to the College. The scholarship is of the value of $£ 50$ per annum, tenable for three years at the College, and will be awarded annually. The holder will be required to pay tuition fees. Dr. Alex Hill, who died on Feb. 27, 1929, became principal of University College, Southampton, in 1913, and steered the College through the difficult War and post-War years, until he resigned in 1920 to devote his energies to the rapidly developing work of the Universities Bureau of the British Empire. From 1920 until his death he was a vice-president of the College, so that he was actively connected with it for a continuous period of sixteen years.

THe following scholarships have been awarded by the Institution of Electrical Engineers for 1930:-

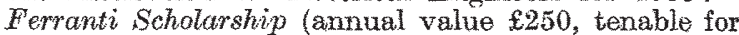
two years) : E. Wilkinson (University of Liverpool); Duddell Scholarship (annual value £150, tenable for three years): T. R. Stretton (Cardiff Technical College); David Hughes Scholarship (value $£ 100$, tenable for one year): H. A. Wainwright (University of Sheffield); Salomons Scholarship (value $£ 100$, tenable for one year) : E. Bell (Armstrong College, Newcastle-on-Tyne); War Thanksgiving Education and Research Fund (No. 1): grants of $£ 50$ each to F. J. Clark (East London College) and Miss W. Harkett (University of Birmingham); Thorrowgood Scholarship (annual value $£ 25$, tenable for two years) : J.F.H. Tyler (Southern Railway Company).

Tex Mond Nickel Company, Ltd., Imperial Chemical House, london, S.W.1, has arranged three exhibits showing aspects of the nickel industry, which are available, free of charge, to colleges, technical institutions, schools, ete., in connexion with conversaziones or to illustrate class or open lectures. Exhibit No.1, illustrating "The Versatility of Nickel ", was available last year. Exhibit No. 2 illustrates "The Extraction of Nickel by the Mond Process" , and consists of flow sheot, photographs, samples of intermediate and fine products, letterpress, and booklets. Exhibit No. 3 illustrates "The Properties and Applications of Nickel and its Alloys", and consists of samples of products made in many different alloys, photographs, lettorpress, and booklets. Lectures illustrated by travelling exhibits or lantern slides are also given by members of the firm's staff.

No. 3182 , Vot. 126] 